\title{
LITERASI KEUANGAN, PERSEPSI DAN KEPERCAYAAN TERHADAP LOYALITAS BERASURANSI
}

\author{
Devi Ria Wibowo \\ STIE PERBANAS SURABAYA
}

\begin{abstract}
Insurance emerges due to unlimited human needs while resources are limited. One of the benefits is protection to gain safety. The need of insurance protection sourced from overcome uncertainty. The purpose of this study to determine the effect of financial literacy and perception of insurance loyalty and mediated trust. Data analysis techniques using SEM in WarpPLS, there are 188 respondents in Indonesia with those used in this study. Based on the results of the study, financial literacy has no significant effect on insurance loyalty. Perception and Trust have a significant effect on insurance loyalty. Trust mediates the effect of financial literacy and perceptions on insurance loyalty.
\end{abstract}

Keywords : Financial literacy; Perception; Trust; Insurance

Correspondence to : deviriawibowo13@gmail.com

\begin{abstract}
ABSTRAK
Asuransi timbul karena kebutuhan manusia yang tidak terbatas, namun alat pemuas kebutuhan yang terbatas. Salah satunya perlindungan terhadap rasa aman. Kebutuhan terhadap perlindungan asuransi bersumber dari keinginan untuk mengatasi ketidakpastian. Tujuan dari penelitian ini adalah untuk mengetahui pengaruh pada literasi keuangan dan persepsi terhadap loyalitas berasuransi serta di mediasi kepercayaan. Teknik analisis data menggunakan SEM pada WarpPLS, terdapat 188 responden di Indonesia yang menjadi responden dalam penelitian ini. Berdasarkan hasil penelitian, literasi keuangan tidak memiliki pengaruh signifikan terhadap loyalitas berasuransi. Persepsi dan Kepercayaan memiliki pengaruh signifikan terhadap loyalitas berasuransi. Kepercayaan memediasi pengaruh literasi keuangan dan persepsi terhadap loyalitas berasuransi.
\end{abstract}

Kata kunci $\quad$ : Literasi Keuangan; Persepsi; Kepercayaan; Asuransi

Korespondensi : deviriawibowo13@gmail.com 


\section{PENDAHULUAN}

Sepanjang tahun 2018 pada bisnis industri asuransi jiwa nasional terus tumbuh. Tercatat bahwa pertumbuhan pada pendapatan premi gabungan asuransi jiwa dan unit link di Indonesia pada kuartal kedua 2018 naik 5,5\% menjadi Rp93,5 triliun dibanding periode sama 2017 (website resmi AAJI, diakses pada 28 Agustus 2018). Penduduk Indonesia berjumlah 254,9 juta jiwa (website resmi BPS, diakses pada 25 September 2015) dimana persentase pengguna asuransi jiwa hanya sebesar 6,6 persen (website resmi AAJI, diakses pada 06 November 2018). Hal ini menunjukkan bahwa masih banyak penduduk Indonesia yang belum melakukan tindakan meminimalisir risiko dalam bentuk penggunaan asuransi jiwa. Terdapat beberapa faktor yang mempengaruhi loyalitas dari individu dalam berasuransi jiwa seperti faktor persepsi, literasi keuangan dan kepercayaan.

Literasi keuangan yang dimiliki seseorang merupakan kemampuannya dalam merencanakan keuangan secara baik dengan melakukan suatu tindakan-tindakan pencegahan yang tepat terhadap risiko kerugian, sehingga pendistribusian keuangan dapat dilakukan dengan tepat (Mahdzan \& Peter Victorian, 2013).

Pada tingkat pengetahuan keuangan individu terhadap produk asuransi unit link dari tahun ke tahun mengalami kenaikan, adanya hal tersebut tidak menutup kemungkinan masih banyak individu yang belum menggunakan asuransi unit link. Banyak individu yang berpersepsi tentang asuransi dimana masih menganggap bahwa asuransi bukanlah kebutuhan pokok yang harus dimiliki. Seorang individu yang melakukan pengambilan keputusan untuk menggunakan asuransi didasarkan karena faktor tertentu untuk meminimalisir risiko sakit kritis, kekhawatiran jika terjadi kecelakan, cacat tetap total, usia tua maupun meninggal dunia yang akan dialami di masa depan. Menurut Kotler dan
Keller (2012) persepsi yang dimiliki seseorang merupakan suatu proses yang dapat digunakan oleh setiap individu dalam memilih, menginterpretasi, dan mengorganisasi masukkan informasi sehingga dapat menciptakan suatu gambaran yang dapat memiliki arti tersendiri.

Individu memiliki persepsi terhadap barang atau jasa yang akan dimiliki akan memperhatikan berbagai faktor yang dapat mempengaruhi persepsinya. Menurut Robbin (2016, 203), terdapat tiga faktor yang dapat mempengaruhi persepsi individu yaitu meliputi target dan obyek, pelaku persepsi, serta situasi. Selain itu penelitian dari Chaudhary (2016) menunjukan bahwa terdapat enam faktor yang dapat mempengaruhi persepsi yaitu layanan yang disesuaikan dan tepat waktu, reputasi pada perusahaan yang lebih baik, kualitas terhadap layanan yang lebih efektif, mengutamakan pada kenyamanan pelanggan, manfaat serta hubungan pada pelanggan yang baik yang dapat mempengaruhi persepsi individu terhadap loyalitas membeli polis asuransi jiwa. Indikator yang mengukur persepsi menurut Chen, Yan, Fan, Gordon (2015) berupa sembilan persepsi terhadap produk seperti harga, waktu, kualitas, produk, pelayanan, niai, kesehatan, kerahasiaan dan sosial. Selain itu, terdapat tiga hal yang mempengaruhi persepsi manfaat yaitu harga rendah, seleksi produk dan pembelian. Banyaknya indikator yang digunakan dalam mengukur variabel persepsi sehingga nantinya akan dilakukan analisis faktor.

Kepercayaan seseorang terhadap produk atau jasa dapat dikatakan sebagai harapan terhadap penyedia jasa sehingga dapat dipercaya dan diandalkan dalam memenuhi semuanya janjinya (Siagian \& Cahyono, 2014). Kepercayaan pada seseorang dapat menimbulkan keinginan dalam memulai menggunakan maupun melakukan proses penggunaan barang maupun jasa secara berkelanjutan yang 
diperuntukan bagi calon pelanggan maupun pelanggan. Menurut Chen \& Chang (2012) dalam membentuk kepercayaan seseorang terdapat empat indikator yakni : kepercayaan mengenai kehandalan kinerja, kepercayaan akan reputasi yang baik, kepercayaan terhadap keamanan dalam melakukan transaksi serta kepercayaan dalam melakukan Tindakan.

Pada penjabaran latar belakang tersebut, peneliti tertarik untuk melakukan penelitian dengan judul "Pengaruh Literasi Keuangan dan Persepsi Terhadap Loyalitas Berasuransi Dimediasi Kepercayaan". dengan mengambil sampel di wilayah Seluruh Indonesia

\section{TINJAUAN PUSTAKA}

Asuransi Unit Link

Pengertian dari Asuransi unit link merupakan asuransi yang memiliki dua kantong, yaitu kantong untuk proteksi dan kantong investasi. Uang premi yang dibayarkan sebagian digunakan untuk proteksi dan sebagian lagi akan ditempatkan pada reksadana dalam bentuk unit link. Menurut Maharani (2015) asuransi proteksi atau asuransi jiwa pada unit link merupakan ketidakmampuan sesorang dalam pertanggungan pada jiwa dan memenuhi semua kebutuhan keluarga, hal ini terjadi karena adanya kemungkinan individu dapat meninggal sebelum masa tuanya ataupun hidup yang terlalu lama. Selain itu, pada asuransi unitlink pemegang polis dapat memilih investasi yang akan di tempatkan baik pada reksadana dalam bentuk saham, reksadana pendapatan tetap, reksadana campuran, atau pasar uang. Tujuan dari asuransi jiwa adalaj menanggung sesorang dari kerugian finansial yang dihadapi terkadang tak terduga dan disebabkan karena meninggalnya terlalu cepat maupun masa hidupnya terlalu lama.

\section{Loyalitas Berasuransi}

Dasar dari loyalitas pelanggan yaitu perilaku individu dalam melakukan pembelian maupun pemakaian terhadap barang atau jasa yang dilakukan secara berulang-ulang dan bertujuan untuk membangun kesetian terhadap pelanggan pada suatu produk atau jasa yang sudah dihasilkan. Tonder (2016) Indikator loyalitas berasuransi adalah kesetiaan terhadap pembelian produk, harapan terhadap perusahaan asuransi, merekomendasikan produk asuransi, melakukan pembayaran secara rutin, tidak menghentikan pembayaran premi

\section{Literasi Keuangan}

Mahdzan \& Peter Victorian (2013) mengungkapkan bahwa literasi keuangan merupakan suatu kebutuhan yang mendasar bagi setiap individu yang nantinya diharapkan agar dapat menghindar dari berbagai permasalahan keuangan. Kemampuan setiap orang dalam merencanakan keuangan berbeda, mereka melakukan berbagai tindakan-tindakan pencegahan yang tepat terhadap risiko kerugian dan pada akhirnya dapat melakukan pendistribusian keuangan secara tepat dan sesuai dengan harapan Kesulitan dalam mengelola keuangan bukan hanya dilihat dari fungsi pendapatan namun perlu juga mengetahui kesalahan pengelola keuangan yang dilakukan. Literasi keuangan dapat digambarkan sebagai seperangkat pengetahuan dan keterampilan dalam masalah keuangan. Memilih kemampuan untuk menerapkan pengetahuan dalam praktik kategori terpisah yang disebut sebagai kompetensi keuangan.

\section{Persepsi}

Menurut Robbins \& Judge (2013, 169) persepsi merupakan suatu proses setiap individu dalam mengatur dan menginterpretasikan dirinya terhadap kesan-kesan sensoris mereka yang dapat memberikan arti untuk lingkungan sekitar mereka. Proses yang dilalui persepsi kemudian didefinisikan menjadi sebuah informasi atas dasar perjanjian timbal balik 
antara individu dan pihak perusahaan asuransi sehingga dapat membentuk hubungan yang baik. Persepsi individu memiliki tiga aspek meliputi seleksi, organisasi, dan interpretasi. Sementara itu, menurut Robbin (2016, 203), faktor yang dapat mempengaruhi persepsi terdiri dari tiga yaitu pelaku persepsi, target dan obyek, serta situasi. Menurut Chaudhary (2016) terdapat enam faktor yang dapat mempengaruhi persepsi individu dalam loyalitas berasuransi yaitu tepat waktu, kualitas dari layanan yang lebih efektif, layanan yang disesuaikan dan reputasi yang dimiliki perusahaan baik, kenyamanan pada setiap pelanggan, manfaat nyata dan hubungan dengan pelanggan yang sehat. Pada faktor yang dapat mempengaruhi persepsi tersebut dijalankan dengan baik kepada pelanggan akan menciptakan loyalitas terhadap produk/jasa. Merujuk pada penelitian Mathur dan Paul (2015) indikator yang digunakan untuk mengukur persepsi adalah manfaat nyata, harga, layanan, agen asuransi, kualitas dan reputasi perusahaan.

\section{Kepercayaan}

Kepercayaan merupakan bentuk sikap yang ditunjukkan kepada seseorang jika sudah merasa cukup untuk mengetahui dan menyimpulkan suatu kebenaran pada dirinya serta kesediaan untuk bertindak berdasarkan keyakinan tentang motif pihak lain dan tingkat resiko yang terlibat dengan tindakan. Kepercayaan yang dimiliki seseorang merupakan suatu harapan pada dirinya bahwa penyedia barang atau jasa dapat dipercaya mapun diandalkan dalam memenuhi semua janjinya (Siagian \& Cahyono, 2014). Kepercayaan seseorang juga dapat memberikan peningkatan keinginan dalam proses mulai menggunakan maupun dalam penggunaan barang atau jasa secara berkelanjutan bagi calon pelanggan maupun pelanggan.
Kerangka Pemikiran

Gambaran kerangka penelitian pada penelitian ini yaitu melihat pengaruh dari dua variabel independen yaitu literasi keuangan dan persepsi terhadap loyalitas berasuransi yang menjadi variabel dependen serta kepercayaan sebagai variabel mediasi. Sehingga kerangka pemikiran ini dapat disusun sebagai berikut

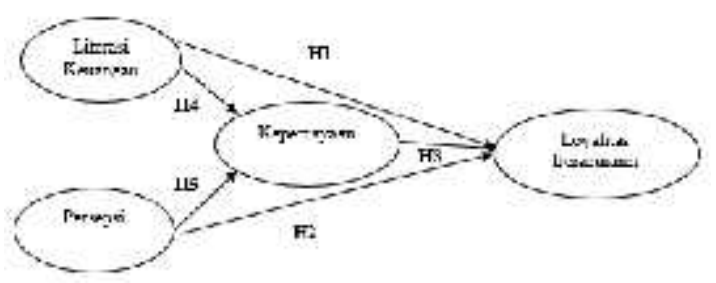

Gambar 1. Kerangka Pemikiran

Pada kerangka pemikiran yang telah dibentuk di atas, berikut merupakan hipotesis yang dapat diperoleh:

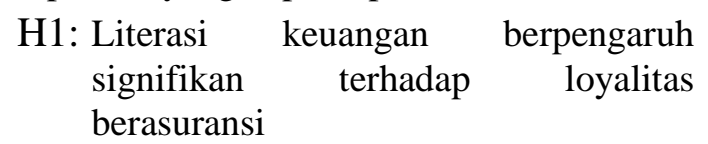

H2: Persepsi berpengaruh signifikan terhadap loyalitas berasuransi

H3: Kepercayaan berpengaruh signifikan terhadap loyalitas berasuransi

H4: Kepercayaan memediasi pengaruh literasi keuangan terhadap loyalitas berasuransi

H5: Kepercayaan memediasi pengaruh persepsi terhadap loyalitas berasuransi

\section{METODE PENELITIAN}

Data yang digunakan pada penelitian ini merupakan data primer. Dapa Primer ini didapatkan dengan menggunakan metode survei yaitu menyebarkan kuesioner maupun google form yang harus dilengkapi pengisian oleh responden. Pada variabel persepsi dan kepercayaan menggunakan skala ordinal (Likert) sedangkan variabel literasi keuangan menggunakan skala rasio.

Peneliti akan menyebarkan kuesioner dan google form kemudian diisi oleh responden. Lalu peneliti dapat mengolah dan menganalisis data. 


\begin{abstract}
Populasi yang diambil dalam penelitian ini merupakan masyarakat yang berada maupun tinggal di Indonesia. Teknik pengambilan sampel dalam penelitian ini yaitu menggunakan non random sampling. Sanusi (2011:94) mengungkapkan bahwa non random sampling merupakan tipe dalam pengambilan sampel dengan tidak mempertimbangkan suatu peluang, dimana tidak semua orang memiliki kesempatan yang sama. Pemilihan sampel pada penelitian ini, peneliti menggunakan dua metode sekaligus yaitu purposive sampling dan convenience sampling.
\end{abstract}

Tujuan dari peneliti melakukan sampel dengan menggunakan purposive sampling karena terdapat kriteria tertentu yang diambil dari penelitian serta disesuaikan dengan tujuan dari penelitian itu sendiri. Sedangkan penggunaan teknik convenience sampling karena mempermudah peneliti dalam mengambil sampel sehingga dapat menghemat waktu dan biaya.

Teknik analisis data yang digunakan pada penelitian ini terdapat dua teknik yaitu analisis deskriptif, analisis faktor dan analisis statistik.

Mudrajad Kuncoro (2013:198) dalam bukunya mengungkapkan bahwa pada penggunaan dalam analisis deskriptiif merupakan bagian yang relevan dalam keseluruhan data yang sudah ada nantinya dikelompokkan maupun akan dipisahkan disesuaikan dengan komponennya agar data dapat lebih mudah dikelola. Adanya beberapa pengaturan maupun pengurutan data yang dapat menerima informasi secara deskriptif sehingga nantinya akan menjawab semua pertanyaan pertanyaan didalam definisi masalah yang ada.

Analisis faktor memiliki proses dalam melakukan percobaan sehingga menemukan adanya hubungan antar variabel, baik itu variabel independen satu dengan variabel independent yang lain. Hal ini dapat dibuat dengan satu kesatuan maupun berdasarkan beberapa kumpulan variabel yang lebih sedikit. Melakukan pembandingan dengan jumlah variabel awal merupakan cara efektif tanpa kehilangan informasi penting yang dibutuhkan dan terkandung didalamnya. Variabel yang akan diuji menggunakan analisis faktor adalah variabel persepsi karena banyaknya sudut pandang persepsi dari berbagai penelitian
Permasalahan yang terjadi pada penelitian ini dan untuk menguji hipotesis yang ada harus menggunakan analisis statistik. Adapun alat uji statistik yang nantinya akan digunakan pada penelitian ini adalah Partial Least Square (PLS). Menurut Imam Ghozali (2012:7) Partial Least Square (PLS) merupakan suatu metoda yang dapat digunakan untuk memprediksi konstruk dalam suatu model dengan banyak faktor dan berhubungan colinear.

\section{HASIL PENELITIAN}

Variabel yang nantinya akan dilakukan pengujian dengan menggunakan analisis faktor adalah variabel persepsi. Pada variabel persepsi ini memiliki banyak sudut pandang yang berbeda dalam faktor maupun indikator persepsi dari berbagai penelitian yang ada saat ini. Adapun terdapat beberapa indikator dari variabel persepsi yang akan dianalisis.

Tabel 1. Indikator Persepsi

\begin{tabular}{cc}
\hline Variabel Persepsi & Indikator \\
\hline P1 & Keuntungan Asuransi \\
\hline P2 & Larga \\
\hline P3 & Manfaat Nyata \\
\hline P4 & \\
\hline P5 & \\
\hline P6 & Agen Asuransi \\
\hline P7 & Kualitas \\
\hline P8 & \\
\hline P9 & \\
\hline P10 & \\
\hline P11 & \\
\hline P12 & \\
\hline P13 & \\
\hline P14 & \\
\hline P15 & \\
\hline
\end{tabular}

\section{Menguji KMO dan Bartlett's Test}

Analisis faktor dapat dikatakan dapat dilakukan atau tidak yaitu dengan melihat dari matrik korelasi secara keseluruhan, dimana KMO dan Barlette's Test > 0.5. 
TABEL 2. Hasil KMO and Bartlett's Test

$$
\begin{gathered}
\text { Kaiser-Meyer-Olkin Measure of } \\
\text { Sampling Adequacy. }
\end{gathered}
$$

\begin{tabular}{llr}
\hline $\begin{array}{l}\text { Bartlett's Test } \\
\text { of Sphericity }\end{array}$ & $\begin{array}{l}\text { Approx. Chi- } \\
\text { Square }\end{array}$ & 993.988 \\
\cline { 2 - 3 } & Df & 105 \\
\cline { 2 - 3 } & Sig. & .000 \\
\hline
\end{tabular}

Uji KMO dapat dilakukan dengan tujuan untuk mengetahui apa saja faktorfaktor dalam penelitian ini valid atau tidak. Menurut Imam Gozali (2009:307), angka KMO dan Barlette's Test harus di atas $(0,5)$. Hasil pengujian dari analisis faktor berdasarkan pada tabel di atas maka dapat disimpulkan bahwa analisis faktor dapat dilakukan, dimana KMO dan Barlette's Test hasilnya adalah 0,821 dengan nilai signifikan 0,000 pada angka tersebut sudah diatas 0,5 dan nilai signifikansi $<0,05$.
Menentukan Jumlah Faktor Baru yang Terbentuk

Langkah analisis faktor selanjutnya adalah mengamati dan menentukan beberapa faktor baru yang mungkin terbentuk berdasarkan 15 persepsi yang dianalisis tersebut. Terdapat 5 komponen dengan nilai Total Initial Eigenvalues yang terbentuk lebih besar dari 1 (Eigenvalues $>$ 1). Faktor-faktor yang mempunyai nilai eigen lebih besar dari 1.0 dapat dipertahankan dalam model. Lima komponen terssebut adalah komponen 1, 2, 3, 4 dan 5 pada tabel 3 .

Berdasarkan tabel tersebut diketahui bahwa faktor baru yang dapat diolah maksimal lima faktor, langkah selanjutnya adalah menentukan masing- masing variabel atau item indikator akan masuk ke dalam faktor yang mana dari kelima faktor baru tersebut. Berdasarkan nilai kumulatif 67,455 persen makan lima komponen tersebut dapat menjelasakan persepsi loyalitas berasuransi masyarakat di Indonesia.

TABEL 3. Komponen Pembentuk Faktor Baru

\begin{tabular}{ccccccc}
\hline & \multicolumn{5}{c}{ Total Variance Explained } \\
\hline \multirow{2}{*}{$\begin{array}{c}\text { Comp } \\
\text { onent }\end{array}$} & Total & $\begin{array}{c}\text { I of } \\
\text { Variance }\end{array}$ & $\begin{array}{c}\text { Cumulativ } \\
\text { e \% }\end{array}$ & Total & $\begin{array}{c}\text { \% of } \\
\text { Variance }\end{array}$ & Cumulative \% \\
\hline 1 & 5.046 & 33.639 & 33.639 & 2.834 & 18.896 & 18.896 \\
\hline 2 & 1.573 & 10.487 & 44.126 & 2.336 & 15.576 & 34.473 \\
\hline 3 & 1.228 & 8.188 & 52.314 & 1.818 & 12.120 & 46.592 \\
\hline 4 & 1.170 & 7.798 & 60.112 & 1.818 & 12.119 & 58.711 \\
\hline 5 & 1.101 & 7.343 & 67.455 & 1.312 & 8.744 & 67.455 \\
\hline
\end{tabular}

Menentukan Faktor Baru Berdasarkan Analisis Faktor

Berdasarkan pada pengolahan data dengan melihat rotated component matrix untuk pengelompokan item indikator dari hasil pengelompokan tersebut, masingmasing indikator yang dianalisis persepsi terhadap loyalitas berasuransi.

Indikator yang terbentuk yaitu Persepsi

(P13, P14, P12, P15), Persepsi (P9, P10, P8, P11), Persepsi (P5, P4, P6),
Persepsi (P2,P1,P3), dan Persepsi (P5). Pada penelitian yang telah dilakukan ini rotasi yang akan dipakai adalah dengan metode varimax. Mekanisme yang dilakukan dengan menggunakan rotasi varimax adalah dengan membuat korelasi dari item-item yang sudah ada dengan melihat hanya yang dominan terhadap satu faktor. Korelasi yang terdiri dari item yang mendekati nilai mutlak 1 dan 0 pada setiap faktornya, sehingga dapat mempermudah dalam menginterpretasi item yang dominan. Adanya rotasi dapat memudahkan dalam menentukan ke dalam 
faktor satu, faktor dua maupun faktor tiga serta faktor-faktor selanjutnya hingga sampai faktor kelima.

TABEL 4. Hasil Uji Rotated Componen Matrix

\begin{tabular}{cccccc}
\hline & \multicolumn{5}{c}{ Component } \\
\hline & 1 & 2 & 3 & 4 & 5 \\
\hline P13 & .868 & .133 & .119 & .141 & .153 \\
\hline P14 & .836 & .149 & .132 & .129 & .121 \\
\hline P12 & .627 & .259 & .352 & .252 & -.203 \\
\hline P15 & .507 & .415 & .220 & .093 & .168 \\
\hline P9 & .229 & .741 & -.116 & .038 & .230 \\
\hline P10 & .145 & .729 & .079 & .067 & -.305 \\
\hline P8 & - & & & & \\
& .104 & .694 & .178 & .205 & .449 \\
\hline P11 & .406 & .630 & .120 & .283 & -.024 \\
\hline P5 & .295 & .009 & .747 & .117 & -.034 \\
\hline P4 & - & & & & \\
& .060 & .146 & .673 & .172 & .069 \\
\hline P6 & & - & & - & \\
& .330 & .047 & .664 & .056 & .214 \\
\hline P2 & .290 & .198 & .145 & .754 & .163 \\
\hline P1 & & - & & & \\
& .395 & .007 & -.075 & .705 & .216 \\
\hline P3 & - & & & & \\
& .073 & .169 & .218 & .683 & -.191 \\
\hline P7 & .196 & .082 & .149 & .054 & .833 \\
\hline & & & & &
\end{tabular}

Hasil dari tabel diatas dapat dilakukan penjabaran dari penyebaran faktor-faktor yang ada sebagai berikut:

Faktor 1: Terdiri dari dua faktor pembentuk antara lain P12 merupakan fakor kualitas produk dengan nilai loading sebesar 0.627. Selain itu, P13, P14, dan P15 berasal dari faktor reputasi perusahaan dengan nilai loading sebesar $0.868,0.836$, dan 0.507. Sehingga faktor faktor tersebut jika akan diberi nama Percived Quality.

Faktor 2: Terdiri atas tiga faktor pembentuk antara lain P8 merupakan faktor manfaat nyata dimana memiliki nilai loading sebesar 0.694. Pada P9 berasal dari faktor agen asuransi memiliki nilai loading faktor sebesar 0.741. Pada indikator P10 dan P11 merupakan faktor kualitas memiliki nilai loading faktor, 0.729 dan 0.630. Faktor faktor tersebut selanjutnya diberi nama Kepuasan Pelanggan.
Faktor 3: Terdiri atas dua faktor antara lain P4 merupakan faktor layanan dengan nilai loading faktor 0.673. Selain itu, P5 dan P6 merupakan faktor manfaat nyata memiliki nilai loading faktor 0.747 dan 0.664. Selanjutnya dari kedua faktor tersebut diberi nama Kehandalan Produk.

Faktor 4: Terdiri atas tiga faktor antara lain P1 merupakan faktor keuntungan menggunakna asuransi memiliki nilai loading faktor 0.705. Pada P2 merupakan faktor harga dengan nilai loading faktor 0.754. Selain itu, P3 merupakan faktor layanan memiliki nilai loading faktor 0.68 . Faktor faktor tersebut selanjutnya diberi nama Kebutuhan Pelanggan.

Faktor 5: Terdiri atas satu faktor yaitu P7 yang merupakan faktor Manfaat Nyata

\section{Partial Least Square (PLS)}

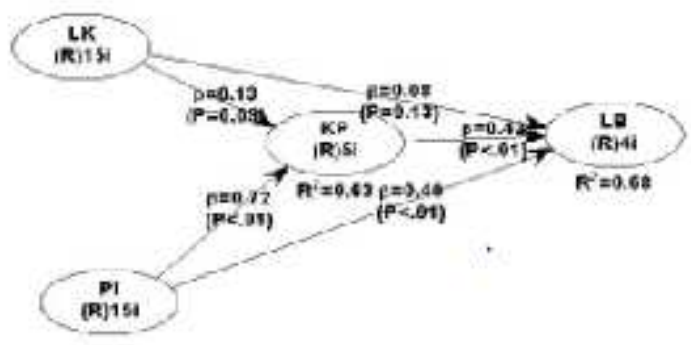

Gambar 2. Uji PLS Sebelum Analisis Faktor

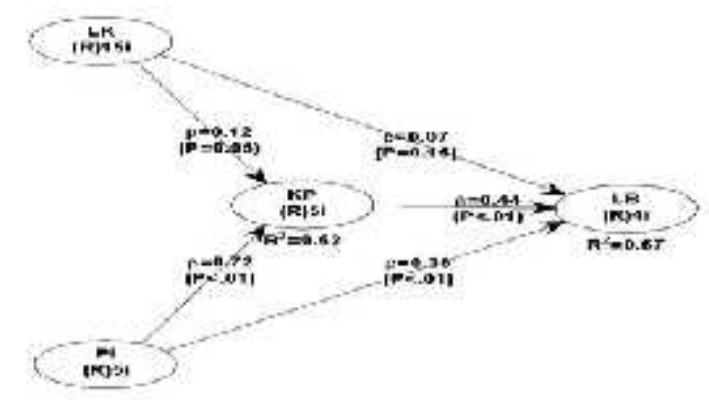

Gambar 3. Uji PLS SetelahAnalisis Faktor

$\begin{array}{ll}\text { LK } & \text { : Literasi Keuangan } \\ \text { PI } & \text { : Persepsi Individu } \\ \text { KP } & \text { : Kepercayaan } \\ \text { LB } & \text { : Loyalitas Berasuransi }\end{array}$

Berikut adalah hasil ringkasan dari estimasi model untuk path coefficients dan $p$ values pada PLS setelah dilakukan analisis faktor 
TABEL 5. Path Coefficients dan P-Values

\begin{tabular}{|c|c|c|c|}
\hline Keterangan & $\begin{array}{c}\text { Nilai } \\
\text { Koefisien } \\
\beta\end{array}$ & $\begin{array}{c}P- \\
\text { values }\end{array}$ & $\begin{array}{c}\text { Hasil } \\
\text { Pengujian }\end{array}$ \\
\hline $\mathrm{LK} \rightarrow \mathrm{LB}$ & 0,07 & 0.16 & H1 ditolak \\
\hline $\mathrm{PI} \rightarrow \mathrm{LB}$ & 0,72 & $<0,01$ & $\begin{array}{c}\mathrm{H} 2 \\
\text { diterima } \\
\end{array}$ \\
\hline $\mathrm{KP} \rightarrow \mathrm{LB}$ & 0.44 & $<0,01$ & $\begin{array}{c}\mathrm{H} 3 \\
\text { diterima }\end{array}$ \\
\hline $\begin{aligned} \mathrm{LK} & \rightarrow \mathrm{KP} \\
& \rightarrow \mathrm{LB}\end{aligned}$ & $\begin{array}{c}0,12 * 0,44 \\
=0,053\end{array}$ & $<0,01$ & $\begin{array}{c}\mathrm{H} 4 \\
\text { diterima }\end{array}$ \\
\hline \multirow{2}{*}{$\begin{array}{c}\mathrm{PI} \rightarrow \underset{\mathrm{KP}}{\mathrm{KB}} \rightarrow \\
\quad\end{array}$} & $0.72 * 0.44$ & \multirow[t]{2}{*}{$<0,01$} & \multirow{2}{*}{$\begin{array}{c}\mathrm{H} 5 \\
\text { diterima }\end{array}$} \\
\hline & $=0.317$ & & \\
\hline
\end{tabular}

Analisis R-Squared $\left(\mathrm{R}^{2}\right)$

TABEL 6 R-Squared Coefficients

\begin{tabular}{cc}
\hline Keterangan & $\begin{array}{c}\text { R- } \\
\text { squared }\end{array}$ \\
\hline KP & 0,616 \\
\hline LB & 0,67 \\
\hline
\end{tabular}

Nilai R- squared (R2) pada variabel kepercayaan (KP) adalah sebesar 0,616. Hasil ini dapat menjelaskan bahwa 61,6 persen dari variasi yang terjadi pada variabel kepercayaan dipengaruhi oleh variabel literasi keuangan dan persepsi serta 38,4 persen sisanya variabel lain yang dapat mempengaruhi dimana berada di luar model estimasi peneliti. Kemudian, jika dilihat dari nilai $R$-squared (R2) variabel loyalitas berasuransi adalah sebesar 0,67. Hasil tersebut membuktikan bahwa 67 persen variasi yang terjadi pada variabel loyalitas berasuransi dipengaruhi secara simultan oleh variabel literasi keuangan, variabel persepsi dan variabel kepercayaan, sedangkan 33 persen lainnya variabel lain yang dapat mempengaruhi di luar model estimasi peneliti. Hasil dari $R$-squared (R2) pada tabel tersebut dapat dilihat bahwa variabel kepercayaan yang sebesar 0.616 dan pada variabel loyalitas berasuransi yang sebesar 0,67 dapat disimpulkan bahwa model pada penelitian ini kuat karena memiliki nilai $R$-squared $(R 2)$ yang lebih dari 0,25 (Ghozali dan Latan, 2014 : 106).

\section{PEMBAHASAN}

Hipotesis 1

H1 : Literasi keuangan tidak berpengaruh signifikan terhadap loyalitas berasuransi

Bila koefisien $\beta$ yang dimiliki variabel literasi keuangan terhadap loyalitas berasuransi adalah sebesar 0,07. Jika dilihat dari $\mathrm{p}$-value yang dimiliki variabel literasi keuangan terhadap variabel loyalitas berasuransi adalah 0,16 dimana nilai $\mathrm{p}$ value lebih besar dari 0,01 sehingga dapat dikatakan bahwa literasi keuangan tidak berpengaruh signifikan terhadap loyalitas berasuransi. Berdasarkan pada hasil tersebut pada variabel literasi keuangan dapat disimpulkan bahwa $\mathrm{H} 1$ ditolak dan HO diterima, artinya literasi keuangan tidak berpengaruh signifikan terhadap loyalitas berasuransi. Artinya, semakin tinggi literasi keuangan pada tingkatan tertentu yang dimiliki seseorang tidak mampu atau belum dapat mempengaruhi seseorang loyal atau tidak menggunakan asuransi. Hal ini, disebabkan perbedaan pola pikir antar masyarakat di berbagai wilayah terhadap pendistribusian keuangan mereka secara tepat. Jumlah produk keuangan saat ini memiliki berbagai jenis dan terus mengalami peningkatan, begitu pula kebutuhan masyarakat umum yang harus mengetahui tentang berbagai produk tersebut. Namun, tidak semua kelompok dalam masyarakat di berbagai wilayah Indonesia memiliki layanan pengetahuan yang sama dalam memahami informasi tentang produk keuangan, yang mungkin penting bagi kesejahteraan keuangan mereka Tingkat literasi masyarakat tersebut juga dipengaruhi faktor-faktor lain seperti pengetahuan produk yang rendah, kepercayaan rendah, rendahnya kesadaran akan risiko dan biasanya perilaku pengambilan keputusan.

Penelitian ini memiliki persamaan hasil dengan penelitian Adiandari \& Winata (2017) dimana pada penelitiannya menunjukkan bahwa variabel literasi keuangan memiliki pengaruh yang tidak signifikan atau tidak memiliki pengaruh terhadap kepemilikan individu dalam berasuransi. Selain itu, menurut Driver, 
Brimbel, Yushita (2017) pada hasil penelitiannya bahwa tingkat literasi keuangan individu yang rendah masih banyak berada di wilayah negara-negara maju maupun yang pada di negara-negara sedang berkembang termasuk di Indonesia.

Hipotesis 2 : Persepsi berpengaruh signifikan terhadap loyalitas berasuransi.

Bila koefisien $\beta$ yang dimiliki variabel persepsi terhadap loyalitas berasuransi adalah dengan nilai koevisien 0,72 . Hasil tersebut membuktikan bahwa pada variabel persepsi memiliki pengaruh terhadap loyalitas berasuransi. Jika dilihat dari pvalue yang dimiliki variabel persepsi terhadap variabel loyalitas berasuransi kurang dari 0,01 dari p-value tersebut dapat dikatakan bahwa persepsi memiliki pengaruh yang signifikan terhadap loyalitas berasuransi. Berdasarkan kedua penjelasan tersebut dapat disimpulkan bahwa $\mathrm{H} 1$ pada variabel persepsi ini diterima dan $\mathrm{H} 0$ ditolak, artinya persepsi memiliki pengaruh signifikan terhadap loyalitas berasuransi. Artinya, pada variabel persepsi semakin tinggi persepsi yang dimiliki seseorang maka akan semakin baik orang tersebut dalam merencanakan asuransi sebaliknya juga jika semakin rendah persepsi seseorang maka akan semakin rendah juga dalam melakukan perencanaan asuransi.

Penelitian ini sejalan dengan penelitian Ari \& Dewi (2014) yang membahas mengenai pengaruh pada persepsi individu terhadap asuransi berperan dalam loyalitas seseorang menggunakan asuransi jiwa. Didukung dengan peneitian Lestari (2018) dimana persepsi risiko pada individu memiliki pengaruh signifikan terhadap keputusan dalam menggunakan asuransi Jiwa. Selain itu, hasil peneliatan Chen, Yan, Fan, Gordon (2015) mengungkapkan bahwa adanya persepsi risiko individu dan persepsi manfaat memiliki pengaruh terhadap kepuasan membeli.

Hipotesis 3: Kepercayaan berpengaruh signifikan terhadap loyalitas berasuransi.

Bila koefisien $\beta$ yang dimiliki variabel kepercayaan terhadap loyalitas berasuransi adalah 0,44 . Nilai tersebut membuktikan bahwa kepercayaan memiliki pengaruh terhadap loyalitas berasuransi. Jika dilihat dari p-value yang dimiliki variabel kepercayaan terhadap variabel loyalitas berasuransi kurang dari 0,01 maka dapat dikatakan bahwa variabel kepercayaan memiliki pengaruh signifikan terhadap loyalitas berasuransi. Berdasarkan kedua penjelasan tersebut membuktikan bahwa pada variabel kepercayaan $\mathrm{H} 1$ diterima dan H0 ditolak, artinya variabel kepercayaan memiliki pengaruh signifikan terhadap loyalitas berasuransi. Semakin tinggi kepercayaan yang dimiliki seseorang dalam dirinya maka akan semakin baik orang tersebut untuk loyal terhadap asuransi atau sebaliknya juga jika semakin rendah kepercayaan yang dimiliki seseorang maka akan semakin buruk orang tersebut untuk loyal terhadap asuransi. Kepercayaan individu juga dapat meningkatkan keinginan seseorang dalam memulai menggunakan barang atau jasa atau proses penggunaan barang atau jasa tersebut secara berkelanjutan bagi bertujuan bagi calon pelanggan maupun untuk pelanggan yang sudah memiliki asuransi. Penelitian ini sejalan dengan penelitian Jayantari \& Seminari (2018) kepercayaan memiliki pengaruh positif dan signifikan terhadap niat dalam menggunakan produk serta adanya peran kepercayaan secara signifikan yang mampu memediasi variabel persepsi risiko dan niat menggunakan produk. Sehingga dapat dikatakan bahwa niat individu dalam menggunakan barang ataupun jasa akan menjadi semakin tinggi, jika kepercayaan yang dimiliki individu tersebut mampu menurunkan persepsi persepsi risiko yang mungkin nantinya akan ditimbulkan.

Hipotesis 4: Kepercayaan memediasi pengaruh literasi keuangan terhadap loyalitas berasuransi

Literasi keuangan tidak memiliki pengaruh signifikan terhadap loyalitas berasuransi, variabel literasi keuangan memiliki pengaruh signifikan terhadap kepercayaan, dan kepercayaan juga memiliki pengaruh signifikan terhadap loyalitas dalam berasuransi. Berdasarkan penjelasan ini maka dapat disimpulkan bahwa kepercayaan memediasi pengaruh literasi keuangan terhadap loyalitas berasuransi secara penuh. Hasil tersebut disimpulkan bahwah $\mathrm{H} 1$ diterima dan $\mathrm{H} 0$ ditolak, artinya kepercayaan dapat memediasi pengaruh literasi keuangan terhadap loyalitas berasuransi. Penelitian 
ini sejalan dengan penelitian Chen, Yan, Fan, Gordon (2015) Kepercayaan ditemukan memediasi hubungan antara persepsi manfaat terhadap kepuasan pembelian. Didukung penelitian dari Paidi, Kaltum, Helmi (2018) kepercayaan memediasi pengaruh pada citra perusahaan, layanan pada perusahaan maupun kualitas produk terhadap loyalitas berasuransi. Menurut Tonder (2016) kepercayaan dan komitmen sebagai variabel mediator dari hubungan antara saran kualitas serta loyalitas pada pelanggan

Hipotesis 5 : Kepercayaan memediasi pengaruh persepsi terhadap loyalitas berasuransi

Persepsi berpengaruh signifikan terhadap loyalitas berasuransi, persepsi memiliki pengaruh signifikan terhadap kepercayaan, dan kepercayaan memiliki pengaruh signifikan terhadap variabel loyalitas berasuransi. Berdasarkan penjelasan ini maka dapat disimpulkan bahwa variabel kepercayaan dapat memediasi pengaruh persepsi terhadap loyalitas berasuransi secara parsial. Dengan demikian maka dapat diketahui H1 diterima dan HO ditolak, artinya kepercayaan dapat memediasi pengaruh variabel persepsi terhadap loyalitas berasuransi. Penelitian ini sejalan dengan penelitian beberapa penelitian yang sudah ada seperti penelitian dari Chen, Yan, Fan, Gordon (2015) Kepercayaan ditemukan memediasi hubungan antara persepsi manfaat terhadap kepuasan pembelian. Didukung penelitian dari Paidi, Kaltum, Helmi (2018) kepercayaan memediasi pengaruh variabel citra merk perusahaan, kualitas produk dan layanan yang diberikan terhadap loyalitas berasuransi. Menurut Tonder (2016) kepercayaan dan komitmen merupakan variabel mediator pada hubungan antara saran kualitas produk dan loyalitas pada pelanggan.

\section{KESIMPULAN}

Hasil dari pengujian dan analisis yang sudah dilakukan oleh peneliti, maka dapat di simpulkan bahwa literasi keuangan tidak berpengaruh signifikan terhadap loyalitas berasuransi, persepsi berpengaruh signifikan terhadap loyalitas berasuransi, kepercayaan berpengaruh signifikan terhadap loyalitas berasuransi, kepercayaan memediasi pengaruh literasi keuangan terhadap loyalitas berasuransi serta kepercayaan memediasi pengaruh persepsi terhadap loyalitas berasuransi.

Penelitian yang telah dilakukan peneliti, maka terdapat beberapa saran yang dapat disampaikan bagi pihak-pihak yang terkait. Pertama, bagi peneliti selanjutnya diharapkan dapat memaksimalkan penggunaan kuesioner online, memperluas lingkup wilayah penelitian, dan meratakan jumlah penyebaran responden pada masingmasing wilayah penelitian serta membuat model dengan menggunakan variabel lainnya sehingga akan dapat diketahui berbagai faktor lain yang dapat mempengaruhi loyalitas berasuransi selain literasi keuangan, persepsi dan kepercayaan. Kedua, bagi masyarakat diharapkan adanya edukasi dari pemerintah, dalam hal ini Otoritas Jasa keuangan tentang asuransi dan pentingnya melakukan proteksi pada masa yang akan datang. Hal ini agar masyarakat memiliki pengetahuan keuangan dan membentuk loyalitas berasuransi yang lebih baik kedepannya. Selain itu, masyarakat juga diharapkan agar lebih bijak dalam mengelola keuangan, cenderung untuk melakukan perencanaan terhadap penggunaan asuransi.

\section{DAFTAR PUSTAKA}

Adiandari, A. M., Winata, H., \& Yuliani, Y. (2017). Literasi Keuangan dan Kepemilikan Asuransi Jiwa: Observasi di Institusi Keuangan Sumatera Barat. Hal 289-301

Ari. (2014). Peran Persepsi Individu Terhadap Asuransi dan Model Kepercayaan Kesehatan dalam Pengambilan Keputusan Menggunakan Asuransi Jiwa. Jurnal Psikologi Udayana, 1(2), 381-388.

Chaudhary. (2016). Customer Perception Regarding Life Insurance Policies: A Factor Analitical Approach. Pacific Business Review International.Vol. 9 No. 6 Hal 52-61

Chen, Yan, Fan, \& Gordon. (2015). The join moderating rele of trust 
propensity and gender on customers' online shopping behavior. Computers in Human Behavior. Vol.43. Hal. 272-283

Chen dan Chang (2012). Enhance Green Purchas Intentions, The Roles Of Green Perceived Value, Green Perceived Risk, and Green Trust. Journal of Management Decision, 50 (3), Hal 502-520

Ghozali. (2012). Partial Least Square : Konsep, Teknik dan Aplikasi. SmartPLS 2.0 M3. Semarang: Badan Penerbit Universitas Diponegoro.

Jayantari, I. A. A. U., \& Seminari, N. K. (2018). Peran Kepercayaan Memediasi Persepsi Risiko terhadap Niat Menggunakan Mandiri Mobile Banking di Kota Denpasar. E-Jurnal Manajemen, 7 (5), 2621-2651.

Kotler. \& Keller. (2012). Marketing Manajement. Jakarta: Penerbit Erlangga

Kaltum \& Helmi . (2018). Image of Indonesian Life Insurance Companies by Their Client's Trust. Academy of Strategic Management Journal, 17(2), 1-9.

Kuncoro,Mudrajat. 2013. Metode Riset Bisnis \& Ekonomi. Jakarta: Erlangga

Lestari, W. (2018). Keputusan Berasuransi, Studi Demografi Dan Persepsional. Ekspektra: Jurnal Bisnis dan Manajemen, 2(1), 44-55.

Mahdzan \& Victorian. 2013, The Determinants of Life Insurance Deman: A Focus on Saving Motives and Financial Literacy. Journal of Asian Social Science. Vol. 9. No.5 Hal 274

Maharani, Zukhri, \& Suwena. (2015). Analisis Faktor-faktor yang mempengaruhi masyarakat di kota singaraja memiliki program asuransi unitlink. Jurnal Pendidikan Ekonomi Undiksha, Vol.5. No.1.
Robbins. (2016). Perilaku Organisasi. Jakarta: PT. Indeks Kelompok Gramedia

Robbins, Judge. (2013) . Perilaku Organisasi. Jakarta: PT. Indeks Kelompok Gramedia

Siagian \& Cahyo. (2014). Analisis Website Quality, Trust dan Loyalty Pelanggan Online Shop. Jurnal Manajemen Pemasaran Fakultas Ekonomi Universitas Kristen Petra. Vol.8. No.2. Hal 55-61

Tonder. 2016. Trust and Commitment as Mediators of The Reliationship Between Quality Advice and Customer Loyalty. The Journal of Applied Business Research. Vol. 32. No. 1. Hal 290 - 302

Website

resmi

AAJI

(https://www.aaji.or.id/ diakses pada 28 Agustus 2018)

Website resmi AAJI (https://www.aaji.or.id/ diakses pada 06 November 2018)

Website resmi BPS (https://www.bps.go.id/ diakses pada 25 September 2015)

Yushita (2017). Pentingnya literasi keuangan bagi pengelolaan keuangan pribadi. Nominal, Barometer Riset Akuntansi dan Manajemen. Vol. 6. No.1 